\title{
Printing of Thin Walls using DMLS
}

Milan Daňa, Ivana Zetková, Pavel Hanzl

Regional Technological Institute, University of West Bohemia - Faculty of Mechanical Engineeering, Univerzitní 8, Pilsen 306 14, Czech Republic. E-mail: danam@rti.zcu.cz, zetkova@rti.zcu.cz, hanzlp@rti.zcu.cz

This work deals with the problematics of 3D printing. Additive manufacturing (AM) covers a lot of principles of producing products and prototypes, for example, Direct Metal Laser Sintering (DMLS). This principle is based on sintering metal powder in thin layers, layer by layer. This theme is very extensive and a very popular research area. The paper is focused on printing thin walls. The material for printing was Maraging Steel MS1. This material achieves great mechanical properties like as high strength and high hardness. The tensile strength can be up to 2000 MPa after age hardening. The printer used was an EOS M290. The effects of different part position on safety of printing are compared. Also, the effect of support structures on accuracy was investigated. The main part of the paper is focused on an experiment where thin walls are printed and subsequently evaluated. The influences and limitations were investigated. The measurements were carried out on a Blickle Multicheck PC500 microscope.

Keywords: 3D print, DMLS, MS1 - 1.2709, Wall thickness

\section{Acknowledgement}

The present contribution has been prepared under the project LO1502 'Development of the Regional Technological Institute' under the auspices of the National Sustainability Programme I of the Ministry of Education of the Czech Republic aimed to support research, experimental development and innovation.

\section{References}

[1] FOUSOVÁ, M. VOJTĚCH, D. KUBÁSEK, J. DVORSKÝ, D. MACHOVÁ, M. (2015). 3D Printing as an Alternative to Casting, Forging and Machining Technologies. In Manufacturing Technology. November 2015, Vol. 15,No.5. s. 809-814. ISSN 1213-2489

[2] EOS MaragingSteel MS1. EOS. [online]. [cit. 2016-08-10]. Availible from: http://gpiprototype.com/images/PDF/EOS_MaragingSteel_MS1_en.pdf.

[3] KUČEROVÁ, L. ZETKOVÁ, I. (2016). Metallography of 3D Printed 1.2709 Tool Steel. In: Manufacturing Technology. February 2016, Vol. 16, No.1. s. 140 -144. ISSN 1213-2489

[4] Daniel Thomas. The Development of Design Rules for Selective Laser Melting. Ph.D. Thesis National Centre for Product Design \& Development Research University of Wales Institute. Availible from: https://repository.cardiffmet.ac.uk/dspace/handle/10369/913

[5] ČAPKOVÁ, V. (2015). Restrictive parameters of 3D printing .Pilsen 2015. Thesis. SUPERVISOR Ing. Zetek, Ph.D, Availible from: https://otik.uk.zcu.cz/handle/11025/9318

[6] HANZL, P. (2016). The influence of a volume fraction on load capacity of the gyroid structure made of maraging steel using the DMLS technology. Pilsen 2016. Thesis. Supervisor Ing. Zetek, Ph.D

[7] HANZL, P., ZETEK, M., BAKŠA, T., KROUPA, T. (2015). The influence of processing parameters on the mechanical properties of SLM parts. In Procedia Engineering. Vídeň: Elsevier, 2015. s. 1405-1413. ISBN: 978-3901509-99-5 , ISSN: 1877-7058

[8] ANTONYSAMY A. A. (2012). Microstructure, Texture and Mechanical Property Evolution during Additive Manufacturing of Ti6Al4V Alloy for Aerospace Applications. Manchester 2012. Doctoral thesis. Supervisor Prof. Philip Prangnell. Availible from: https://www.escholar.manchester.ac.uk/uk-ac-man-scw:160535

[9] EPMA European Powder Metallurgy Association. Introduction to additive manufacturing technology - A guide for Designers and Engineers. Availible from: http://www.epma.com/doc_details/427-introduction-to-additive-manufacturing-technology

[10] Matilainen, V. Benchmarking of laser additive manufacturing proces. Bachelor's thesis. Finland 2012. Availible from: http://www.doria.fi/bitstream/handle/10024/84863/BSc\%20Thesis\%20Matilainen\%20fv.pdf? sequence=1

[11] BINELI A. R. R. PERES A. P. G., JARDINI A. L., FILHO R. M. (2011). DIRECT METAL LASER SINTERING (DMLS): In Technology for design and construction of microreactors. Brasil 2011. 6th brazilian conference on manufacturing engineering. ISSN: 0100-7386 